\title{
Editorial: Mais textos poéticos e um poeta Augusto!
}

O volume 11 da revista eletrônica TextoPoético (órgão oficial do GT Teoria do Texto Poético, da ANPOLL, site www.textopoetico.com.br), ora entregue ao público, é referente ao segundo semestre de 2011 e está organizado do seguinte modo:

A abertura é uma entrevista inédita e exclusiva com o poeta Augusto de Campos, que, por ocasião de seu $80^{\circ}$ aniversário, gentilmente a concedeu a Mayra Berto Massuda e Antônio Donizeti Pires.

A seção a seguir apresenta oito estudos sobre temas variados da poesia universal, sendo que os quatro primeiros enfocam a lírica brasileira mais contemporânea, respectivamente: "Política, amor e coprologia: Aspectos humorísticos da poesia de Paulo Leminski”, de Lucas dos Passos e Wilberth Salgueiro (UFES); “'O intrincado torto lirismo' de Afonso Henriques Neto", de Marleide Anchieta de Lima (UFF); "Perfis de Orfeu na poesia brasileira recente", de Antônio Donizeti Pires (UNESP/Araraquara); e “'O espelho perverso do poeta': A poesia de Donizete Galvão em $O$ homem inacabado", de Audrey Castañón de Mattos e Márcia Valéria Zamboni Gobbi (UNESP/Araraquara).

Os próximos quatro artigos continuam a tratar de poesia lírica, mas agora sob um viés comparativo mais efetivo, em que se ressalta tanto a relação da lírica com outros sistemas culturais e/ou com as outras artes, quanto a visão suscitada pela poesia e pelas poetisas brasileiras na literatura portuguesa recente. Assim, temos: "Ascese cristã, nirvana búdico e ordens do discurso: Poesia e pensamento em Jorge de Lima e Wang Wei”, de Leandro Durazzo (Universidade de Lisboa), em que o autor evidencia as diferentes concepções de religião do poeta brasileiro modernista e do chinês Wang Wei (séc. VII), adepto do budismo Chan/Zen; "Vulliamy e Braque por Francis Ponge", em que a autora, Roseli de Fátima D. A. Barbosa (UNICAMP), estuda o modo sui generis como o poeta francês Ponge atualiza as relações poesia e pintura, em poemashomenagem aos artistas Vulliamy e Braque. No próximo trabalho, "Adoniran Barbosa e o pogréssio de São Paulo", de Wilson José Flores Jr. (UFRJ), o que se tem é o estudo das letras dos sambas do compositor paulista, com ênfase no aspecto crítico das canções, afim às contradições inerentes ao processo de modernização de São Paulo e do Brasil. Enfim, o oitavo e último artigo, "A viagem de Maria Teresa Horta pelo Brasil", 
de Ilca Vieira de Oliveira (UNIMONTES), enaltece a viagem que a poeta portuguesa empreendeu por nosso país em 2007, de que resultou o livro Poemas do Brasil (2009).

A seção de resenhas contém seis trabalhos, sendo cinco apreciações críticas de livros de poesia editados e/ou reeditados entre 2009 e 2010, nesta ordem: Joana Prada Silvério (UNESP/Araraquara), em "Monodrama: Primeiras impressões do absurdo", apresenta o livro de Carlito Azevedo lançado em 2009; Wilberth Salgueiro (UFES), em "Poesia, segredo e juízo em Cinco ciclos e meio século (2009), de Glauco Mattoso", faz uma contundente análise crítica desta e de outras obras de Mattoso; Patrícia Aparecida Antonio (UNESP/Araraquara), em "Notícias de um país selvagem: A lírica originária de Rodrigo Petronio", apresenta criticamente o último livro (2009) do poeta paulista; Nicia Petreceli Zucolo (UFAM/USP), em “A mutilação do sagrado: A poética profana em Aleijão, de Eduardo Sterzi”, comenta o livro publicado há pouco por Sterzi; e Lino Machado (UFES), em "Poemóbiles: Dupla autoria, realização única", faz a recensão da terceira edição (2010) do livro-objeto que Augusto de Campos e Julio Plaza publicaram originalmente em 1974. No sexto e último trabalho, "Um breve balanço da poesia de Augusto de Campos - 80 anos de vida do autor", a pesquisadora de IC Mayra Berto Massuda (UNESP/Araraquara; bolsa FAPESP) faz a transcrição da fala do poeta informalmente conduzida por Ivan Marques (USP) - na quinta edição da "Balada Literária”, evento realizado em São Paulo em 20 de novembro de 2010 em homenagem a Augusto de Campos. A transcrição soma-se à resenha de Lino Machado e à entrevista com que abrimos o presente volume da TextoPoético, em justo reconhecimento a um dos criadores do Concretismo brasileiro.

Enfim, agradecemos aos queridos amigos do GT Teoria do Texto Poético (ANPOLL) e aos colegas profissionais das Letras (de várias latitudes e longitudes do Brasil) que nos ajudaram, com a emissão de pareceres circunstanciados, no processo de avaliação dos muitos artigos e resenhas recebidos para a revista, e esperamos que nossos habituais (e novos) leitores possam aproveitar ao máximo o rico conteúdo que temos a satisfação e a honra de tornar público. Boa leitura a todos! 
Prof. Dr. Antônio Donizeti Pires (UNESP/Araraquara) Profa. Dra. Solange Fiuza Cardoso Yokozawa (UFG/Goiânia) Coordenadores do GT Teoria do Texto Poético (ANPOLL) 